\title{
Scotland as an Independent Small State: Where would it seek shelter?
}

\author{
Alyson JK Bailes, Adjunct Professor of Political Science, University of \\ Iceland, Baldur Thorhallsson, Professor of Political Science, University of \\ Iceland and Rachael Lorna Johnstone, Senior Lecturer in Law, University \\ of Akureyri
}

\begin{abstract}
A planned referendum in 2014 on Scottish independence gives cause to examine that scenario in the light of small state studies and recent European experience. One of the best-supported assumptions in small state literature is that small countries need to form alliances and seek protection from larger neighboring states and/or international institutions. Small European states have generally sought shelter from the European Union (EU) and NATO. This study confirms that an independent Scotland would need strategic, political, economic and societal shelter, and could look for the various elements within existing European institutions, from its closest southern and northern neighbours, and from the US. However, protection may come with a certain cost - just as union with another entity does at present.
\end{abstract}

Keywords: Scotland, independence, small states, strategy, 'shelter', European institutions, Nordic affairs, Arctic.

\section{Introduction}

Since the end of the Cold War in 1989 the Euro-Atlantic area has seen many new small states spring into existence, notably but not only with the break-up of former Yugoslavia and of the former Soviet Union. All these states except the most Easterly ones

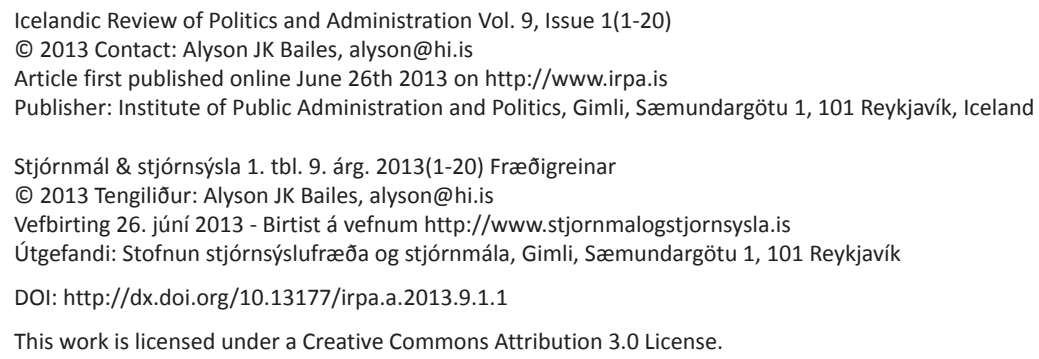


quickly chose to seek full membership of NATO or the European Union (EU), or both, to serve a wide range of national interests including the need for security.

Not many further openings remain for new 'smalls' to emerge in this region, but three of them lie on the North-western periphery of Europe. Scotland, already enjoying considerable devolved powers within the United Kingdom (UK), will hold a referendum in late 2014 asking its citizenry whether to seek full independence. The Faroe Islands and Greenland, parts of the Danish realm with home-rule status, have a constitutional right to initiate moves towards independence - but have so far not chosen to do so.

This article is not about whether Scotland will, or should, vote for independence in 2014. It is written from an international relations standpoint and makes only the necessary minimum of references to Scottish or British internal affairs, including such important aspects of the independence question as taxation and economic viability. Instead it looks at the Scottish case in the light of small state theory, and more specifically, of the concept that posits such states' need for strategic, political, economic and societal shelter. What solutions exist to meet this need, and which ones have been used by new small states during the late $20^{\text {th }}$-early $21^{\text {st }}$ century in Europe? How well would Scotland's own situation in the event of independence fit this framework, and what specific choices might it face? Given Scotland's geo-strategic position and political culture, could comparisons and lessons from the five Nordic countries be relevant?

This topic is not exactly new, as the ongoing UK debate has often touched on Scotland's 'smallness', usually in connection with arguments over its ability to stand alone. Smallness has been cited as a reason why Scotland would need to stay in/join the EU, and also as a reason why its presence need not damage but might benefit the EU itself (Murkens 2001; Scottish National Party 2012). There has been frequent mention of Nordic lessons and models for an independent Scotland - without necessarily calling the Nordics 'small' (e.g. Hanlon and Kärki 2011) - and the Scottish National Party (SNP) has depicted the chance to follow Nordic examples as one likely benefit of independence (e.g. Salmond 2012). With some exceptions, however (e.g. Keating 2011; Donald and Hutton 2011), the discourse of 'smallness' has developed in a context of political debate and partisanship, or as a way of framing specific practical issues, rather than seeking enlightenment from the scholarly literature on small states. The present article seeks to add value by concentrating upon the latter approach.

First, the theoretical and analytical framework for the study will be explained. Part 2 of the text then briefly reviews Scotland's historical and modern constitutional position and the framing of the independence issue. Part 3 discusses first the general, then the Nordic-related and Arctic-related, challenges and options that would arise for an independent Scotland as a 'small state' seeking shelter. Part 4 summarizes the conclusions.

\section{Small States and shelter: Theories in Small States Studies and 'Realpolitik'}

Generally, the International Relations (IR) literature argues that small states need a protecting power. A small entity can seek protection/shelter from a larger neighboring state 
or from international or regional organization/s (Keohane 1969; Handel 1981). Also, norms and rules of the international system may provide protection from aggressive neighbors. The essence of traditional IR perspectives lies in their overwhelming focus on capabilities of states in terms of number of inhabitants and size of GDP, territory and military (Neumann and Gstöhl 2004). On this approach, the importance of strategic alliance-making for small states is based on their greater political and economic vulnerability compared with large states.

Yet the IR literature cannot agree on how to define the size of states; and its offspring, small state studies, has not produced a common unifying definition either (Archer and Nugent 2002). Rather, small state writings have identified several alternative ways to measure states' sizes, and to analyze their international activities, beyond the traditional variables mentioned above. For instance, Mouritzen and Wivel (2005) argue that small state studies should move to a relational definition, shifting the focus from the power that states possess to the power they exercise. A state may be weak in one context but simultaneously powerful in another, while a great power may be defined as a country capable of changing the conditions for policy-making (e.g. UK, Germany and France in the EU). There are other alternatives such as a more comprehensive definition including both material and subjective factors (Thorhallsson and Wivel 2006; Archer and Nugent 2002); an exclusive focus on how domestic and international actors perceive the power of the state in question; or a clearer focus on countries' domestic and international capabilities, reflected in the competence of their public administration and foreign service (Thorhallsson 2006). That said, small state studies do not need a 'final' universal definition of how to define a small state. It makes sense for each and every case study to select its own definition(s) depending on which states are being compared and why: it makes a difference whether Scotland is compared to France, or to Luxembourg.

Most definitions would agree that the five Nordic states are 'small'. Figure 1 lists these states in declining order of size (according to population) and shows that an independent Scotland would fit well into their range of population and gross domestic project per capita. Although more thickly populated than most, Scotland would share the strategic challenges of a long indented coastline, communications stretched across wilderness areas, and territorial waters containing important resources to protect (oil, gas, fish). Unlike Iceland, Greenland and the Faroes, the pro-independence movement wants Scotland to create national armed forces (discussed further below); but like all Nordic states it would still be at a deep strategic disadvantage vis-à-vis the main potentially problematic actor in the region, namely Russia. It would have less than a twelfth of the population of, and far less military strength than, its nearest neighbour - the remaining $\mathrm{UK}(\mathrm{rUK})$. It would also be more exposed, geopolitically, than $\mathrm{rUK}$ to the wider Arctic zone which is expected to witness rapid development and turbulence - if not actual conflict - i.a. because of climate change (Heininen and Southcott, 2010). 
Figure 1. Scotland and Nordic nations: comparison of variables commonly used to define size of states

\begin{tabular}{|c|c|c|c|c|c|c|}
\hline & \multirow[t]{3}{*}{$\begin{array}{r}\text { Population } \\
\text { (thousands) }\end{array}$} & \multirow{3}{*}{$\begin{array}{l}\text { Territory } \\
\text { (sq. km.) }\end{array}$} & \multirow[t]{3}{*}{$\begin{array}{r}\text { GDP per } \\
\text { capita (\$) }\end{array}$} & \multicolumn{3}{|c|}{ Military Capacity } \\
\hline & & & & \multirow[t]{2}{*}{$\begin{array}{c}\text { Military Spending } \\
\text { (\% of GDP) }\end{array}$} & \multicolumn{2}{|c|}{ Armed Force Personnel } \\
\hline & & & & & Active & Reserves \\
\hline Sweden & 9.453 & 450.295 & 41.485 & 1,3 & 21.070 & 200.000 \\
\hline Denmark & 5.574 & 43.094 & 40.945 & 1,5 & 18.707 & 53.507 \\
\hline Finland & 5.387 & 338.145 & 37.485 & 1,4 & 22.250 & 350.000 \\
\hline Scotland ${ }^{i}$ & 5.254 & 78.772 & 42.124 & (UK 2,6) & (UK 178.470) & (UK 82.274) \\
\hline Norway & 4.952 & 323.802 & 61.047 & 1,5 & 26.450 & 45.250 \\
\hline Iceland & 319 & 103.000 & 36.483 & none & none & none \\
\hline Greenland & 57 & 2.166 .086 & - & none & none & none \\
\hline Faroe Islands & 49 & 1.393 & - & none & none & none \\
\hline
\end{tabular}

Population information is from the World Bank for the year 2011; territory information is from the CIA World Factbook for the year 2013; GDP information (in International Dollars) is from the Scottish Government (2013); military expenditure from SIPRI data for 2010; armed force personnel figures from IISS Military Balance 2011.

i Scottish data from National Statistics Scotland; GDP includes a proportionate allocation of UK oil/gas revenues.

The shelter small states look for is not, however, only military or strategic. From the mid-1980s, many scholars cited the impressive economic performance of a number of small developed and developing states to claim that smaller entities might be better suited to deal with challenges of the new global economy (e.g. Katzenstein 1984; 1985). The international financial crisis of 2008 and the economic collapse of small 'successful' states, such as Iceland and Ireland, have quashed such discussions at least for the time being. The small state literature has recalled its core concept of vulnerability and focused afresh on the economic component (Thorhallsson and Kirby 2012). Small states are generally seen as disproportionately vulnerable due to their small domestic market, reliance on import and export, and exposure to international economic fluctuations (Katzenstein 1984; 1985). Importantly, this is said to undermine their ability to 'defend' themselves, making them dependent here too on others' protection for survival in a hostile international environment (Thorhallsson 2006). Small entities may also be particularly exposed to 'new' threats such as powerful crime and terrorism, and to 'softer' security problems in the environmental, health and other functional spheres: challenges they can only hope to tackle through international cooperation (Bailes and Thorhallsson 2013). Further, small states have less capacity to defend themselves diplomatically and engage in international affairs due to the small size of their public administration and foreign service (Handel 1981) - though no-one any longer contests their ability to gov- 
ern themselves, i.e. to run the necessary domestic apparatus and a basic foreign service. Combined with other factors, this creates pressure to find political shelter with a stronger political entity/community against threats to the national integrity and political norms.

At the same time, many small nations (such as the Benelux and Nordic states) have demonstrated that they can defend their interests in organizations such as the EU (Panke 2010) and significantly contribute to the work of the UN by such means as mediation, peace-keeping, development aid and human rights (Thorhallsson 2012a). Their success has been a result of their administrative working practices in terms of prioritization, informality, flexibility and the autonomy of their officials related to the small size of their bureaucracy (Thorhallsson 2000; 2012a). In this sense and through the specialized resources they may bring (including useful locations), small states have something to give as well as receive when entering into shelter relationships.

Historically, small countries have always sought security protection by larger states (Alesina and Spolaore 2003). Multilateral institutions in the post-Second World War era offered a new alternative, although some countries, such as Iceland, Liechtenstein and Andorra, continued to seek protection partly or solely from their larger neighbours. Hard security was provided for Western Europe by NATO, while the Warsaw Pact provided it in the East. After the Berlin Wall fell, central and some eastern European states gravitated towards NATO and the EU, while others sought alliance with Russia or are still debating their strategic choices. International and regional organizations such as the World Bank, the International Monetary Fund and the EU provided and continue to provide aid and economic shelter, albeit often at the cost of domestic autonomy. Most recently, for example, the EU has offered its members important political shelter in terms of diplomatic backing for receiving IMF assistance, and in other crisis-related international negotiations.

Increasingly, the EU also provides guidelines and practical support for its members in tackling societal challenges such as local environmental protection, transport and infrastructure. It enhances 'soft' security in fields such as energy, crime and migration control and disaster response including pandemic handling (Bailes and Thorhallsson 2013). When it comes to societal and cultural shelter and community-forming, a wider range of groups can come into play: thus in Northern Europe, Nordic Cooperation has provided its members with important economic and societal shelter for more than half a century in terms of a common labour market, passport union and welfare norms. Even if Nordic states' participation in European integration has overshadowed Nordic economic cooperation, cultural, educational and other societal ties remain strongest within the Nordic context. In sum, relations among modern European states have been characterized by multiple alliance formation.

While a traditional hard security shelter serves basically to prevent (or punish) aggression, the function of political, economic and societal shelter for small states has three inter-related phases: reduction of vulnerability and risk before the crisis event; assistance in absorbing shocks when risk goes bad; and help in cleaning up after the event. Within this framework, economic shelter may come (from a state and/or an 
organization) in the form of direct economic assistance and investment, a currency union, beneficial loans, favorable market access, a common market and so forth. Political shelter includes direct and visible diplomatic or operational backing in any given need, and help in achieving favourable organizational rules and norms in the international system (Thorhallsson 2011). Societal shelter may include good external cultural and social communication (Thorhallsson 2012b) in accordance with Rokkan and Urwin's (1983) centre-periphery relations model. Figure 2 illustrates how these various dimensions of shelter are currently provided for the Nordic states and Scotland by states and key regional organizations. Scotland's corresponding options in the case of independence are explored below.

Figure 2. Present economic, political, societal and security shelter of the Nordic states and Scotland

\begin{tabular}{lcccccc}
\hline Shelter Type & Economy & $\begin{array}{c}\text { Currency } \\
\text { union }\end{array}$ & Political & Societal & Hard security & Soft security \\
Sweden & EU & no & EU & EU/NCi & no & EU/Schengen \\
Denmark & EU & DKK(EU)i & EU/NATO & EU/NC & NATO & EU/Schengen \\
Finland & EU & EU & EU & EU/NC & no & EU/Schengen \\
\hline Scotland & UK/EU & UK & UK/EU/NATO & UK/EU & UK/NATO & UK/EU \\
Norway & EEA/EFTA & no & NATO & EEA/NC & NATO & Schengen \\
Iceland & EEA/EFTA & no & NATO & EEA/NC/WNC & NATO/USA & Schengen \\
Greenland & DK & DK & DK/USA/NATO & DK/NC/WNC & DK/USA/NATO & DK/Schengen \\
\hline Faroe Islands & DK & DK & DK/NATO & DK/NC/WNC & DK/NATO & DK/Schengen \\
\hline
\end{tabular}

i Nordic Cooperation. ii Danish krone (DKK) pegged to the Euro. iii European Economic Area/European Free Trade Association. iv West Nordic Cooperation. v Denmark.

All shelter has a cost. Vital (1967) claimed that when small states seek to offset their weaknesses by association or alliance with other states, 'a price must normally be paid in terms of sacrifice of autonomy in the control of national resources and loss of freedom or political maneuver and choice' (Vital 1967, 5). Such penalties certainly exist for small states seeking to join the EU (Bailes and Thorhallsson 2013) and to a lesser extent though in very different ways - for members of NATO and the Nordic Council. It is important to grasp that a small sub-state entity also 'pays' for protection and insurance by a larger partner in a union such as Scotland's with the UK, or the Greenlanders and the Faroese people in their relations with Denmark.

In terms both of theory and Realpolitik, Scotland as an independent small state would need external shelter in multiple dimensions. Its solutions would incur costs different from, and not necessarily lesser than, those carried by the Scottish people within their present union. Section 4 below explores the options and implications further. 


\section{STJÓRNMÁL \& \\ STJÓRNSÝSLA}

\section{Scotland's path and current status}

The creation of a united Scottish state is traditionally credited to Kenneth MacAlpin in the $9^{\text {th }}$ century. Despite frequent wars with England, Scotland remained independent up to 1603; and when James VI of Scotland then also ascended the English throne as James I, the two realms stayed initially separate. Only in 1707 were they combined by a Treaty and parallel Acts of Union to create the present United Kingdom (UK) (Wormald 2005).

The story of campaigns for Scottish autonomy or independence in a modern, constitutional context goes back over a century. ${ }^{1}$ A Scots National League was created in 1921, influenced by the Irish independence struggle, and after further transformations and mergers became the Scottish National Party (SNP) in 1935 (Mitchell, Bennie \& Johns 2011). Scottish self-rule or independence did not, however, emerge as a mainstream political topic until the 1960s, when Winnie Ewing gained the first SNP seat at the Westminster Parliament in 1967. Boosted by the discovery of North Sea oil and the SNP's campaign for Scotland to receive the profits, as many as seven SNP MPs were returned in the 1974 elections. At this stage the Party began campaigning for a separate Scottish Parliament, and the Labour Government of James Callaghan - then allied with the prodevolution ${ }^{2}$ Liberals - agreed to put this proposal and other self-government measures to a referendum in Scotland. The positive vote, however, fell short of the required 40\% of the electorate and the plans had to be shelved. A Conservative win in the May 1979 elections then shut the door temporarily on any questioning of British unity.

Campaigning for a Scottish Parliament revived in the 1990s, and Labour's victory in the 1997 general election opened the way for a new referendum. This time $74.3 \%$ of those voting, or $44.87 \%$ of all Scottish electors, were in favour and $25.7 \%$ of votes were cast against. The first devolved Scottish Parliament was duly elected in mid-1999. The Parliament nominates a First Minister who forms a separate Scottish government, with power to make its own decisions in fields such as police and justice, social services, health, education, agriculture and fisheries, and environment. Foreign affairs and defence matters are reserved to Westminster, but Scottish representatives join in external activities and negotiations that concern them, such as fishery agreements and much EU-related work. Scotland is responsible for fulfilling the UK's international obligations within the fields of its devolved competence. ${ }^{3}$

The SNP led a minority Scottish government from 2007-2011 but won an absolute majority in the 2011 Scottish elections (details in Cairney 2011). First Minister Alex Salmond announced that he would hold a referendum on changing Scotland's status in 2014-5, and launched a public campaign to rally support for independence. The Conservative/Liberal Democrat government in London insisted that Scotland could not decide such matters alone: the terms of Scottish governance were established by UK Parliamentary Acts that could be changed or revoked at any time. While the issues of law and legitimacy remain open to argument, the Scottish and UK governments managed to agree in October 2012 on holding the referendum in late 2014 - before the next Westminster elections - and posing a simple Yes/No question (now agreed as: 
'Should Scotland be an independent country?'). ${ }^{4}$ Only those on the local government electoral roll within Scotland will vote. The SNP has further stated that an independent Scotland would wish to retain the Queen as monarch, the pound sterling as currency, ${ }^{5}$ and Scotland's present borders including Edinburgh's jurisdiction over the Western and Northern isles. ${ }^{6}$

All three major parties at Westminster - Conservative, Labour, and Liberal Democrats - oppose independence for Scotland. So do their Scottish branches, though some would accept further devolution. In the Scottish Parliament, besides the SNP, independence is supported by two Green Party members and three independent members, making up 55\% of all seats. The balance of power between parties differs greatly in Scotland and in the UK as a whole, because of voter choices but also because Scotland uses a proportional representation system (Cairney 2011). In the UK parliamentary elections of 2010, Labour gained 41 seats in Scottish constituencies, the LibDems 11, the SNP 6 and the Conservatives just one. At Westminster, this total of 59 Scottish seats constitutes less than $10 \%$ of the whole number (650), and the SNP have never yet been included in coalition-forming manoeuvres that might give them leverage. Meanwhile, opinion polls have consistently shown only a minority of Scots approving independence: results reported in January-February 2013 (for example) had a range of 28-34\% of respondents in favour and $47-55 \%$ against.

\section{Issues and options under the independence scenario}

In its given, North-west European and 'strong state' context, Scotland's independence - should it ever happen - would be more of a 'velvet divorce' than a violent (conflictdriven) breakaway or radical régime change. The new country's strategy might thus be expected to lean towards continuity at least in external orientation. Further, Scotland's peripheral geographical site and its shortage of neighbours mean that it has few if any truly new options, either in terms of strategic partners or of regional frameworks for shelter. The pre-1603 'Auld Alliance' with France is no longer an answer to potential threats from East and South that would most likely hit France first.

In fact, the SNP have made clear that Scotland would be keen to stay in the European Union and would also wish to remain a full member of NATO. ${ }^{7}$ Current controversy hinges on the conditions on which it could do so and especially, whether it would have a residual right to membership (as a former part of the UK) or would need to apply afresh. The UK Government have published legal advice (Crawford and Boyle 2013) supporting the latter view and stressing that Scotland would have to apply everywhere, including at the United Nations. EU and NATO membership require all existing member states to ratify accession treaties, and some analyses have suggested the UK and others might use this to delay Scottish entry for years, inter alia as a way to protest its secession and deter imitators. ${ }^{8}$

What is clear is that the Scottish situation lacks direct European precedent, as no member state has split up after previously joining NATO and/or the EU. This leaves room for both anti-and pro-independence campaigners to develop their own hypoth- 


\section{STJÓRNMÁL \& \\ STJÓRNSÝSLA}

eses, and use them to sway opinion in the referendum campaign. The resulting clamour should not distract attention from the equally important truths that:

(a) Scottish independence would not happen for some time after a referendum, so the discussion of institutional solutions would start from within a UK framework;

(b) The loss of Scottish territory and population, while highly unlikely to call the rUK's own membership in question, would mean renegotiating the rUK's pracrical arrangements with the EU - budget payments and receipts, institutional representation and voting rights, etc. It would fall to London to try to reassure NATO about the impact of the split on defence readiness in, and contributions from, the British Isles;

(c) Scotland would remain physically attached to the rUK, as its strategic hinterland and main buffer against the traditional line of perceived threat from the Northeast. It would also be the rUK's gateway to the Arctic.

For all these reasons, it is hard to build realistic scenarios where London would wish or be able to treat Scotland in a zero-sum, purely hostile and vengeful way - at least on strategic points - when facing an actual split either post-2014 or later in history. The morning after a 'Yes' vote would witness a new situation where the rUK would also be a demandeur and could only hurt itself by casting Scotland into a limbo of indefinite non-membership. Mutatis mutandis the facts of North European geopolitics should also weigh with other institutional members, balancing any internal-political motives for making trouble. And as discussed below, the US would surely press for minimally disruptive solutions.

Against this background, our analysis will side-step the political claims and arguments deployed in the pre-referendum campaign to ground itself rather in the classic small-state analytical framework deployed above. First we identify four entities - NATO, the EU, the US, and the rUK itself - that seem most suited to meeting Scotland's needs for strategic (hard and soft security), economic, and primary political shelter. The Nordic community, while not a candidate for these tougher protection roles, will then be discussed as a source of other kinds of fellowship and support. Finally we consider potential Scottish interests in the Arctic.

\subsection{Scotland's Needs and Options for Shelter}

The logic of Scotland's seeking its 'hard' strategic shelter from NATO, as now proposed by the SNP, is both external and internal. No other organization offers the collective military strength to deter possible assailants (from any quarter), while also following democratic practices that give a voice to its smallest members. Some Scots may appreciate being part of a trans-Atlantic political community based on democratic values. Others might simply find it a reassuring element of continuity.

From an internal viewpoint, being a small member of NATO gives scope to reduce 


\section{STJÓRNSÝSLA}

national defence spending and avoid building a full range of force capabilities. Small members that deviate from this pattern normally have special reasons for threat-consciousness - such as Estonia, on the Russian border (Bailes and Rafnsson 2012). NATO presses all Allies to meet a norm for $2 \%$ of GDP spent on defence, but sends mixed signals to its smaller members by stressing specialization and complementarity and providing designated reinforcements for them. Under its latest 'Smart Defence' concept, it positively urges members to give up capabilities too limited to be viable (NATO 2013).

NATO's collective budget is very small and not a significant cost for a nation like Scotland. The latter would more probably have to 'pay' by continuing to contribute to NATO-led (as well as EU- or UN-led) military missions abroad; even small states can meet niche requirements in this context, while their presence conveys political solidarity. The SNP have already said they would wish Scotland to join in such tasks when backed by a clear international-legal mandate - i.e., not Iraq-style coalitions (see e.g. Scottish Government 2009, 119). One independent study suggests that viable intervention forces as well as basic territorial defence could be provided for little more than half the money Scottish taxpayers currently contribute to UK defence (Crawford and Marsh 2012), while the SNP itself hopes to save GBP 1 billion annually on the latter figure (Moray Scottish National Party 2012). Much would depend on how the former UK forces were divided; whether Scotland tried to sustain independently viable naval and air arms, with their high equipment costs (the SNP has suggested sharing air and sea bases with the UK which would open up an extra dimension of cover); and other possible changes in force structure such as a revised active/reservist balance.

Would NATO itself want to keep Scotland, as a small 'security importer' with reduced defence spending and capacity, where - moreover - the dominant political movement proposes to declare itself a non-nuclear state and remove the present Trident nuclear submarine base at Faslane (Scottish Government 2009, 120)?' The major headaches this poses for the UK government ${ }^{10}$ should not obscure the fact that very few NATO states now have other people's nuclear forces on their territory, ${ }^{11}$ and a democratic Alliance could hardly bully a new member to retain nuclear capacity in peacetime against its will. Viewed logically, NATO should care about maintaining an effective UK deterrent, and about handling the delicate London-Edinburgh negotiations sensibly, rather than about exactly where the British assets ended up. It would be hard for it to reject Scottish accession on the grounds of military spending or force size, when other recent entrants' performance has varied considerably and Iceland, a founder Ally, has no forces at all. What would probably dominate, ultimately also in London's view, would be the case for maintaining unbroken NATO coverage (with its scope for coherent US reinforcement) across the North Atlantic, and having a Scotland that was a modest contributor rather than a complete free-rider. ${ }^{12}$ 
Figure 3. Hypothetical shelter solutions for Scotland after independence

\begin{tabular}{|c|c|c|c|c|c|}
\hline Economy & Currency union & Political & Societal & Hard Security & Soft security \\
\hline EU/rUK & rUK & EU/NATO/NC & rUK/EU/NC & rUK/US/NATO & rUK/EU \\
\hline
\end{tabular}

As Norway's and Iceland's cases show, the European Union does not automatically appeal to Northern European small states as a shelter. Scotland, however, has already experienced and on balance profited from it for forty years, as seen in figure 2. Anti-EU feeling is less dominant than in rUK: ${ }^{13}$ Brussels may seem a more palatable source of authority than London. Continued presence in the EU would thus be an obvious solution for Scotland's shelter needs in the economic, 'soft' security, societal (as regards concrete functions like communication and infrastructure), and some political dimensions, as indicated by figure 3 .

Recent Irish experience with EU support in the debt crisis underpins this case, but also highlights the price to be paid (Thorhallsson and Kirby 2012). How the overall 'costs' of EU shelter for an independent Scotland might change is a complex question only starting to be probed in public debate. How would Scotland's independently assessed contribution and its receipts from EU funds compare with what it experiences as part of a much larger net-contributing nation? If Scotland had to make a new membership application as many (including the President of the European Commission) believe (Carroll 2012), could it stay outside the Schengen system and maintain a ceiling on its budget contribution as earlier negotiated for the UK? Important questions: but such material concerns have not deterred other recent small applicants to the EU, who reasoned rather in terms of the vulnerabilities they would feel outside the Union, the even less attractive prospect of trusting a national protector, and the support and discipline of a political community grounded in the world's most peaceful values.

Scotland's calculation may be even easier because it faces ceding no sovereignty to Brussels beyond what it is already accustomed to. Only joining the Euro would change that, and the SNP have no such plans at present - though the calculus might change if the UK government's present plans for a referendum on the terms of EU membership led to a complete rUk exit. Granted, Scotland would have far fewer representatives and votes and a much smaller voice at the EU table than the UK or rUK. But that would be offset by the freedom to promote its own distinct European interests - which Scottish representatives, unlike genuinely new entrants, could do with skills honed for decades. They could freely seek new political/tactical alliances with member states both small and large.

As with NATO, the cost-benefit balance from the EU's side should be distinguished from what London might think or feel. The EU faces no obvious strategic danger from leaving Scotland out, and would have alternative ways of working with it (the European 
Economic Area or a Swiss-type bilateral model.) Conversely, however, it has nothing to lose from keeping hold of such a prosperous and peaceful territory, once the political after-shocks of secession and procedural costs of transition were absorbed. Those who agreed to launch accession talks with Iceland in record time in 2009 would have little excuse to go slow on a Scotland already fully compliant. More broadly and perhaps decisively, the EU as a whole and its territories currently doing most business with Scotland - starting with the rUK - would face huge economic, financial and societal uncertainty if Scotland was no longer to be part of the Single Market, the Four Freedoms of human and capital movement, and the common bedrock of EU regulation. This makes it likely, all legal debate and rhetoric aside, that the time of grace before actual Scottish separation would in fact be used to devise ways of keeping the EU system provisionally alive in Scotland and (re?-)establishing Scottish membership fast.

The United States does not want an independent Scotland and has made that clear. Should the break-up nevertheless happen, Washington's attitude is foreshadowed by the rumour that it pressed the SNP leadership to switch in favour of NATO membership. Leaving a strategic black hole North of the rUK and losing access to Scottish facilities - notably for reinforcement purposes - would be a serious setback even for US defence leaders who envisage a gradual strategic 'pivot' away from Europe to Asia. While protective of the rUK's interests, Washington could be expected to urge London to reduce the risks by building a good defence understanding with its new Northern neighbour. Edinburgh would come under equally strong US pressure to cooperate and would have good cause to do so. Its territory's ultimate shelter would be US nuclear and conventional might, as for all Europe's North-western nations including Sweden and Finland. Further, 'the USA is Scotland's largest [overseas] export market and the leading source of inward investment into Scotland' (Scottish Development International n.d.) - investments that would be least disrupted if Scotland's present EU status was preserved. Scottish cultural/societal links with North America are strong, as in Ireland. Overall, one might imagine Washington not only strategically underwriting Scottish/British solutions but actively brokering them, as it has done with London and Dublin at crucial turningpoints - a classic aspect of political shelter.

Under all three headings so far, we have found that good 'shelter' solutions for Scotland depend not least on coming to terms with the $r U K$. In reality, the latter would be Scotland's primary shelter even after independence: in strategic, economic and soft-security terms, and also societally and culturally insofar as cross-border agreement would reduce disruption and distress for ordinary citizens. It is very rare for small nations, especially when materially interdependent with their big neighbours, to adopt shelter solutions against those neighbours. That can only work with the support of a great power - like the US with Taiwan - and Washington's attitude rules it out in the present case. In fact, the SNP's own plan to work within the EU and NATO signals that they envisage Scotland as the closest possible Ally and integrated economic partner of England, Wales and Northern Ireland. Why London would reciprocate may be less obvious from the present anti-independence discourse; but we have seen above that important national 


\section{STJÓRNMÁL \& \\ STJÓRNSÝSLA}

interests would be at stake for the rUK too. A national perimeter protected by a ring of shared institutional membership (EU and EEA) and by warm bilateral relations is, after all, part of the UK's own present strategic shelter.

\subsection{The Nordic Context}

We have noted how pro-independence Scots have deployed Nordic examples to paint an independent Scotland in normatively attractive, reassuring terms. First Minister Salmond has made a point of visiting Norway and Denmark for consultations. The commonalities are most obvious in societal, cultural and habitat terms, as explored by Hassan and Ilett (2011); but the SNP have also invoked strategic models by suggesting that Scotland could follow the Norwegian/Danish NATO precedent of rejecting nuclear and foreignforce stationing in peacetime - or failing that, could work with NATO in the Swedish/ Finnish way (Moray Scottish National Party 2012).

It is implicit here that the Nordics themselves are not an alternative strategic shelter. They all rely themselves on a military alliance or have extensive cooperation with NATO. Iceland and Greenland have special bilateral defence arrangements with the superpower to their West, the United States (figure 2). Further, all are deeply involved in the European integration process as full members or part of the Common Market through the EEA. Greenland and the Faroe Islands are not formally in the EU but draw indirect economic benefits through Denmark. All enjoy a wide range of political and societal protection by the Union's diplomatic strength (see discussion above) and its extensive regional, research, educational and cultural programmes, in addition to soft security benefits not previously available nor currently paralleled elsewhere (Bailes and Thorhallsson 2013).

The SNP's emphasis on EU and NATO membership is thus not un-Nordic, but it is unusual for the region in seeking full double integration (aside from the Euro and Schengen). Sweden and Finland are still not members of NATO. Norway, the Faroes and Greenland have seen the EU as a challenge to their national interests, rather than a source of existential and functional security; and the Icelandic people currently seem to share that view. Greenlanders and the Faroese people have so far preferred to keep traditional cover from Denmark. In other words, all Nordic actors have so far felt justified in seeking some kind of special dispensation or opt-outs in the range of 'sheltering' institutions they belong to. ${ }^{14}$ This could be seen as a 'Northern periphery' phenomenon made possible i.a. by the strength of US strategic cover, or as a reflection of recent and/or idiosyncratic national identities that need to stress singularities as much as regional kinship. At any rate it suggests that Scotland could meaningfully assert a 'Nordic' element in its new identity without having to follow any given model in shelter terms. Its rejection of the Euro and Schengen would mirror the Nordic states' partial engagement with European integration; and a special closeness to the rUK would not exclude it any more than (with much mutatis mutandis) does Finland's relationship of destiny with Russia.

In what sense could the Nordics themselves then add to Scotland's shelter? They could support its negotiation of good bargains with the US and rUK, inside and outside 


\section{STJÓRNSÝSLA}

multilateral institutions, and would have powerful motives for doing so given their own stake in North European stability. At the same time they would provide political inspiration and cover for distinctive characteristics the Scots might want to stress in fields like peace promotion, arms control, humanitarian initiatives and the anti-nuclear stance (as well as social-liberal values at home). Both these roles would provide 'political' shelter for Scotland's willed identity change, as reflected in figure 3. Concrete economic, soft security, and societal benefits could be sought through closer Scottish-Nordic cooperation, including common approaches to the growing Arctic challenge. Scotland's reduced military resources could be optimized by studying Nordic lessons and joining Nordic initiatives like NORDEFCO, the current framework for five-nation defence cooperation (Saxi 2011).

Might this mutually sheltering relationship take institutional form? Scotland could prima facie try to join both Nordic Cooperation (in its parliamentary and governmental dimensions) and the West Nordic Cooperation (WNC) of Iceland, the Faroes, Greenland and coastal Norway. Nordic political and public attitudes would surely be sympathetic, but the precedent involved in granting NC membership might give pause since the Baltic States were earlier denied it. Admitting Scotland to the WNC might be less contentious given its close geographical presence - including Shetland and Orkney and common issues such as oil/gas exploitation. Alternative forms of association, or new 'Nordic-plus' cooperation frameworks, could doubtless be invented.

\subsection{The Arctic Dimension}

Unlike the Nordic connection, the discourse of the Arctic as a region of cooperation or conflict is largely absent in Scottish politics (Johnstone 2012). The Arctic, so far, has been defined more in physical than civilizational terms and all maps would put Scotland to the South of it. Nevertheless, an independent Scotland would become the Arctic's nearest neighbour state outside the Arctic Circle proper. Arctic dynamics would affect it, at the least, in strategic, economic, and ecological terms, giving the High North a significantly higher weighting in Scotland's overall policy balance than it is ever likely to have for London.

Like other small states, Scotland would hope above all for peaceful, environmentally safe and sustainable development in the Arctic. Contamination in the High North would have serious repercussions for the Scottish North Atlantic fishing industry as well as tourism. Open conflict or serious military tension over competing claims to newly accessible resources (exposed on land and under the seabed by ice melting) would be worse, but is actually improbable since the claimants are all committed to settling maritime boundaries in line with the provisions of the UN Convention on Law of the Sea, UNCLOS (Illulisat Declaration 2008; UNCLOS 1982). ${ }^{15}$ Scotland would surely want to become a party to UNCLOS itself, and would be bound by provisions widely considered as part of customary law in the demarcation and exploitation of its own continental shelf. As a small state treasuring the right to dispose freely of its resources, including off-shore, it would gain a new kinship with Greenlanders and other indigenous peoples 
of the North who take similar positions in their own quest for self-determination (Hossain 2011).

In contrast to the still-hypothetical oil and gas rush, disputes over living marine resources are already creating tensions in the High North and can be anticipated to cause continuing problems. Sea creatures have an inconvenient tendency to move in and out of states' exclusive economic zones (EEZs) or exclusive fisheries zones EFZs). ${ }^{16}$ The current mackerel dispute between the EU (representing Scotland) and Norway on the one hand, and Iceland and the Faroe Isles on the other, is just the first example of historic fishing rights being revisited in light of new migration patterns as fish stocks respond to changing ocean temperatures and currents. Such disputes also highlight the importance of Scotland's shelter choices: if within the EU, it would have to let the EU continue negotiating for it, but if standing outside, how much clout would it have in the negotiations (Koivurova et al 2011)? Scotland will also hope for a share of any new fisheries that open up outside EEZs/EFZs, but it is not yet clear how these will be managed - by extending the reach of the two existing fisheries organisations in the North Atlantic, by a new Arctic regional fisheries management organization, or even by leaving an unregulated free-for-all.

The Arctic's dedicated organization for cooperation and dialogue is the Arctic Council. ${ }^{17}$ Albeit a relatively 'soft' institution without - for instance - legal personality or defence competence, the Council is strengthening itself with a permanent secretariat in Tromsø from January 2013. It has engineered a legally binding agreement among its member states ${ }^{18}$ on search and rescue and concluded another, on oil spill preparedness and response, in May 2013. While the Arctic Council itself exists by virtue of 'shelter' from good inter-state relations and other institutions, it plays an irreplaceable stabilizing role and will remain the primary local forum for debating Arctic challenges and forming alliances to tackle them. Currently, the UK has an observer status that allows its officials to attend meetings but not to vote. However, this status can be seen as conditional inasmuch as all observers will now be periodically reviewed to ensure that they are, inter alia, making an adequate contribution to science, respecting the sovereignty and authority of the full members, and giving priority to UNCLOS principles (Graczyk and Koivurova 2013). Practice must be reassessed following in Council's May 2013 meeting when decisions were taken on the more controversial observers, the EU and China. The independence scenario could open up an interesting contest between the rUk and Scotland over what status each or both of them had a right to claim in the Arctic Council system, bearing in mind the sympathy other Arctic peoples might feel (as already mentioned) for Scotland's self-determination campaign.

It can also be argued, however, that Arctic Council status is more of a symbolic than a true 'shelter' issue. Scottish professionals and institutions already take part in the Council's research projects, while the latter's limited competence means that such crucial issues for Scottish interests as Arctic hydrocarbons development, fisheries and trade are handled through different channels altogether. Scotland's small Arctic neighbours might actually need Scotland more than Scotland needs them for specific purposes like search 
and rescue, opening the way for ad hoc solutions as necessary. Here, however, Scotland's putative Arctic agenda becomes tangled with the issue of its general defence arrangements. Recent UK defence restructuring has cut back Scottish bases, making it more difficult inter alia for Scotland to support search and rescue in the High North (Maritime and Coastguard Agency 2011; Johnson 2011). An independent Scotland that was also conscious of its Arctic interests might have extra reason to reassess its north-facing air, naval, and coastguard capabilities (Crawford and Marsh 2012).

\section{Summary and reflections}

All topics covered in this article need much fuller study. They can be re-visited on a firmer basis when the Scottish government publishes its detailed prospectus for handling independence, expected in autumn 2013. London's and other players' attitudes will also solidify over time.

On the basis of presently available information, our findings suggest that seeking NATO and EU membership is more than an adventitious part of the SNP's current programme. It would be a logical choice for an independent Scotland under any foreseeable government and - aside from maximizing continuity - would conform to the mainstream of small-state strategy in Europe since 1990. Scotland's ability to secure such institutional shelters would, however, depend first and foremost on finding a modus vivendi both with the US and with the remainder of the UK. The former holds the ultimate key to Scotland's military and economic viability, while the two parts of the British mainland would remain umbilically linked for strategic as well as economic and social purposes. While this underlines the need for Scotland to come to terms with rUK as its closest and largest neighbouring state, maintaining the cover of a friendly and stable Ally on its Northern border would not be without importance for London either.

Among existing small states, the five Nordics have lived for decades with the same strategic asymmetry that would face Scotland. They have found many-sided shelters while maintaining strong national idiosyncrasies, especially in institutional policy. For Scotland they could not replace a good-neighbourly accord with the rUK; but they could both reinforce it politically - in their own interest - and help balance it with a societal/ cultural community that fostered Scotland's new small-state values.

What would become of all this after a 'No' vote - currently the highest probability - in 2014? Would Scottish energies switch to gaining greater autonomy within the UK, and might any external-policy elements be included? For sure, the clock will not simply go back. If important actors in Scotland grow attached to a specific 'small state' agenda, and forge new Nordic links, in the process of contingency planning, these themes will stay alive one way or the other in Scottish and UK politics.

This study should have demonstrated, meanwhile, that the discipline of small state studies has much to offer also in Scotland's case. Not only does it help provide analytical distance from the heat of current British debates, but it underlines that nothing in an independent Scotland's policy quandaries would be truly unique. Even the need to 
repatriate nuclear weapons from a break-away territory arose in Belarus, Kazakhstan and Ukraine after the Soviet Union's dissolution, where the key to its peaceful handling was leadership from Washington. Scots engaged in contingency planning would do well to look into all such precedents, both from states of similar size and states with similar specific challenges. Small state research in return could gain much from continuing to track Scotland closely, as one of Europe's very few remaining potential test-cases of small state creation.

\section{Notes}

1 As a source for this and the following paragraph see (BBC Scotland 2013).

2 'Devolution' here means delegating former central government powers to regional authorities in Scotland, Wales and Northern Ireland.

3 For more on devolution: http://www.scotlandoffice.gov.uk/scotlandoffice/10181.html, and (Bogdanor 1999).

4 A third, potentially popular 'maximum devolution' (DEVO-MAX) option was mooted but opposed by London. For the October agreement's text see (The Scottish Government 2012a).

5 See http://www.snp.org/vision/better-scotland/independence.

6 This matters because opinion in Shetland and Orkney is markedly less pro-independence than the Scottish norm.

7 The position in favour of staying in NATO required a U-turn in traditional SNP policy and was only narrowly approved at the Party's conference in October 2012.

8 The Spanish province of Catalonia is often mentioned here, but the potential break-up of Belgium is also relevant.

9 We presuppose here that the new Scotland, but not the UK, would have to apply afresh for NATO membership - though transitional arrangements could be made eg by exchanging political statements of guarantee. This is a common-sense hypothesis but still contentious within the British debate.

10 Notably because of the costs of re-providing the Faslane facilities on rUK territory and the impossibility of doing so rapidly (Scottish Affairs Committee of the House of Commons 2012; Chalmers 2012)

11 Belgium, Germany, Italy, Netherlands and Turkey: 5 out of 28 Allied countries.

12 Ireland at present enjoys de facto strategic shelter from the UK, and Scotland might gamble on doing the same even as a non-NATO member - or at least, could pressurize London by hinting that it might.

13 In a January 2012 poll $50 \%$ of Scots who expressed an opinion were for staying the EU but $60 \%$ of Engish respondents wanted to leave.

14 Notably, Denmark's 4 EU opt-outs and Sweden's opt-out from EMU.

15 In practice also, the only Arctic oil and gas deposits commercially viable at present lie well within the uncontested continental shelves of the littoral states (United States Geological Survey 2008).

16 There is no practical difference between an EFZ and an EEZ. The United Kingdom did not claim an EEZ under UNCLOS but claims a 200 nm EFZ under the Fishery Limits Act 1976, article 1.

17 See details at http://www.arctic-council.org.

18 These are Canada, Denmark, Finland, Iceland, Norway, Sweden, Russia and the US.

\section{References}

Alesina, A. and Spolaore, E. (2003). The Size of Nations. Cambridge: The MIT Press.

Archer, C. and Nugent, N. (eds.) (2002). Small States and the European Union. Huntington, NY: Nova Science Publishers. 


\section{STJÓRNSÝSLA}

Bailes, A.J.K. and Rafnsson, Ö.P. (2012). 'Iceland and the EU's Common Security and Defence Policy: Challenge or Opportunity', Stjórnmál og stjórnsýsla 1(8): 109-131.

Bailes, A.J.K. and Thorhallsson, B. (2013). 'Instrumentalizing the European Union in Small State Strategies', European Integration 35(2): 99-115.

BBC Scotland (2013). The Devolution Debate This Century. Accessed 6 February 2013 at http://www.bbc. co.uk/news/special/politics97/devolution/scotland/briefing/c20scot.shtml.

Bogdanor, V. (1999). Devolution in the UK. Oxford: Oxford University Press.

Cairney, P. (2011). The Scottish Political System Since Devolution. Exeter: Imprint Academic.

Carrol, S. (2012). 'Barroso casts doubt on independent Scotland's EU membership rights', The Guardian, 21 September.

Chalmers, M. (2012). The End of an 'Auld Sang': Defence in an Independent Scotland. London: Royal United Service Institute.

CIA World Factbook (2013). The World Factbook. Accessed 4 March 2013 at https://www.cia.gov/library/publications/the-world-factbook/.

Crawford, S. and Boyle, A. (2013). Referendum on the Independence of Scotland - International Law Aspects. Accessed 1 March 2013 at https://www.gov.uk/government/uploads/system/uploads/attachment_data/file/79408/Annex_A.pdf.

Crawford, S. and Marsh, R. (2012). A'the blue bonnets: defending an independent Scotland. London: Royal United Service Institute.

Donald, D. and Hutton, A. (2011). 'Economic Self-Determination: Towards a Political Eonomy of Scottish Citizenship' in G. Hassan og R. Ilett (eds.), Radical Scotland: Arguments for Self-determination. Glasgow: Bell and Bain Ltd.

Graczyk, P. and Koivurova, T. (2013). 'A new era in the Arctic Council's external relations? Broader consequences of the Nuuk observer rules for Arctic governance', Polar Record. Available at CJO2013 doi:10.1017/S0032247412000824.

Handel, M. (1981). Weak states in the international system. London: Frank Cass.

Hanlon, P. and Kärki, F.U. (2011). 'Health, culture and society: a Scottish-Nordic conversation', in G. Hassan og R. Ilett (eds.), Radical Scotland: Arguments for Self-determination. Glasgow: Bell and Bain Ltd.

Hassan, G. and Ilett, R. (eds.) (2011). Radical Scotland: Arguments for Self-determination. Glasgow: Bell and Bain Ltd.

Heininen, L. and Southcott, C. (eds.) (2010). Globalization and the Circumpolar North. Fairbanks: University of Alaska Press.

Hossain, K. (2011). 'The Realization of the Right to Environment and the Right to Development in respect to the Arctic Indigenous Peoples', Polar Law Yearbook 2011. Leiden and Boston: Martinus Nijhoff Publishers.

Illulisat Declaration of the five Arctic powers. (2008). Accessed 5 February 2008 at http://www.oceanlaw.org/downloads/arctic/Ilulissat_Declaration.pdf.

International Institute for Strategic Studies (2011). The Military Balance 2011. Taylor and Francis: London.

Johnson, S. (2011). 'Liam Fox: Scottish “defence footprint” to increase despite RAF Leuchars closure'. The Telegraph, 18 July 2011.

Johnstone, R.L. (2012). 'An Arctic strategy for Scotland', in L. Heinenen (ed.) Arctic Yearbook 2012 (pp. 114-129). Akureyri: Northern Research Forum. Accessed 5 February 2013 at http://www.arcticyearbook.com/images/Articles_2012/Johnstone.pdf.

Katzenstein, P. (1984). Corporatism and Change: Austria, Switzerland and the Politics of Industry. Ithaca and London: Cornell University Press.

Katzenstein, P. (1985). Small States in World Markets: Industrial Policy in Europe. Ithaca and London: Cornell University Press. 
Keating, M. (2011). 'The Political Economy of Self-Determination', in G. Hassan og R. Ilett (eds.), Radical Scotland: Arguments for Self-determination. Glasgow: Bell and Bain Ltd.

Keohane, R.O. (1969). 'Lilliputian's dilemmas: Small states in international politics', International Organiration 23(2): 291-310.

Koivurova, T., Kokko, K., Duyck, S., Sellheim, N. and Stepien, A. (2011). 'The Present and Future Competence of the European Union in the Arctic' in Polar Record 48(04): 361-371.

Maritime and Coastguard Agency. (2011). Blueprint for Future Coastguard Organisation in the UK. November 2011. Accessed 18 February at http://www.dft.gov.uk/mca/blueprint_announcement_final__221111.pdf.

Mitchell, J., Bennie L. and Johns R. (2011). The Scottish National Party: Transition to Power. Oxford: Oxford University Press, 2011.

NATO (2013). Smart Defence. Accessed 7 May 2013 at http://www.nato.int/cps/en/SID-34AEED99772DF4E3/natolive/topics_84268.htm?

Moray Scottish National Party. (2012). Defence Policy Update. Published 16.7.2012. Accessed 1 March 2013 at http://www.moraysnp.org/2012/07/snp-defence-policy-update.html.

Mouritzen, H. and Wivel, A. (2005). The Geopolitics of Euro-Atlantic Integration. London: Routledge.

Murkens, J.E. (2001). Scotland's Place in Europe, The Constitution Unit (University College London). Accessed 14 November 2012 at http://www.ucl.ac.uk/spp/publications/unit-publications/68.pdf.

Neumann, I.B. and Gstöhl, S. (2004). 'Lilliputians in Gulliver's World? Small States in International Relations', Working Paper 1-2004. Reykjavik: Centre for Small State Studies.

Panke, D. (2010). Small States in the European Union: Coping with Structural Disadvantages. London: Ashgate.

Rokkan, S. and Urwin, D.W. (1983). Economy, Territory, Identity: Politics of West European Peripheries. London: Sage Publications.

Salmond, A. (2012). Scotland's place in the world. Hugo Young Memorial Lecture, 25 January 2012. Accessed 3 March 2013 at http://www.guardian.co.uk/politics/2012/jan/25/alex-salmond-hugoyoung-lecture.

Saxi, H.L. (2011). Nordic Defence Cooperation after the Cold War. Oslo Files on Defence and Security, March 2011. Oslo: Norwegian Institute of Defence Studies.

Scottish Affairs Committee of the House of Commons (2012). The Referendum on Scotland: Terminating Trident - Days or Decades? London: The Stationery Office.

Scottish Development International (n.d.). North America Briefing. Accessed 6 February 2013 at http:// www.scottish-enterprise.presscentre.com/International-activity/North-America-briefing-445.aspx.

(The) Scottish Government. (2009). Your Scotland, your voice (White Paper on devolution and independence). Accessed 3 March 2013 at http://www.scotland.gov.uk/Resource/Doc/293639/0090721. pdf.

(The) Scottish Government (2012a). Agreement between the United Kingdom Government and the Scottish Government on a referendum on independence for Scotland. Accessed 12 November 2012 at http://www.scotland.gov.uk/About/Government/concordats/Referendum-on-independence.

(The) Scottish Government (2013). Scotland's International GDP Per Capita Ranking. Accessed 29 May 2013 at http://www.scotland.gov.uk/Resource/0041/00416075.pdf.

Scottish National Party (2012). Senior EU official backs benefits of small states. Published on SNP website 23.12.2012. Accessed 3 March 2013 at http://www.snp.org/media-centre/news/2012/dec/senioreu-official-backs-benefits-small-states.

SIPRI (The Stockholm International Peace Research Institute) (2013). Military Expenditure Database. Accessed 5 March 2013 at http://milexdata.sipri.org/.

Thorhallsson, B. (2006). 'The Size of States in the European Union: Theoretical and Conceptual Perspectives', European Integration 28(1): 7-31.

Thorhallsson, B. (2011). 'Domestic buffer versus external shelter: viability of small states in the new globalised economy', European Political Science, Symposium 10(3): 324-336. 


\section{STJÓRNSÝSLA}

Thorhallsson, B. (2012a). 'Small States in the UN Security Council: Means of Influence?', Hague Journal of Diplomacy 7(2): 135-160.

Thorhallsson, B. (2012b). 'Iceland's external affairs in the Middle Ages: The shelter of the Norwegian sea power', Stjórnmál og stjórnsísla 1(8): 5-37.

Thorhallsson, B. and Kirby, P. (2012). 'Financial Crisis in Iceland and Ireland: Does EU and Euro membership matter?', Journal of Common Market Studies 50(5): 801-818.

Thorhallsson, B. and Wivel, A. (2006). 'Small States in the European Union: What Do We know and What Would We Like to Know?', Cambridge Review of International Affairs 19(4): 651-668.

UNCLOS (United Nations Convention on the Law of the Sea) (1982), 1833 UNTS 397.

United States Geological Survey (2008). Circum-Arctic resource appraisal: estimates of undiscovered oil and gas north of the Arctic circle. Accessed 18 February 2013 at http://pubs.usgs.gov/fs/2008/3049/fs20083049.pdf.

Vital, D. (1967). The Inequality of States: A Study of the Small Power in International Relations. Oxford: Clarendon Press.

(The) World Bank (2013). Countries and economies. Accessed 4 March 2013 at http://data.worldbank.org/ country.

Wormald, J. (2005). Scotland: A History. Oxford: Oxford University Press. 